\title{
INTERWENCJA UBOCZNA SAMOISTNA PO STRONIE POZWANEGO \\ A PRZEKSZTAŁCENIE PODMIOTOWE W TRYBIE ART. 194 § 3 \\ KODEKSU POSTĘPOWANIA CYWILNEGO
}

\section{Wstęp}

Istota interwencji ubocznej samoistnej, uregulowanej w art. 81 Kodeksu postępowania cywilnego ${ }^{1}$, sprowadza się do stworzenia możliwości wstąpienia do toczącego się procesu osoby trzeciej, pozostającej poza nim, ale zainteresowanej jego wynikiem $z$ uwagi na to, że zapadłe $w$ tym procesie orzeczenie wywrze bezpośredni wpływ na jej sferę prawną². Oznacza to, że wyrok, jaki zapadnie w sprawie odniesie bezpośredni skutek także $\mathrm{w}$ relacji pomiędzy interwenientem ubocznym samoistnym a przeciwnikiem strony, do której ten interwenient przystąpił.

Interwenient uboczny samoistny to podmiot, który ze względu na więź materialnoprawną, jaka łączy go ze stronami procesu, mógłby występować w nim jako strona, ale z różnych powodów nie został ani pozwany, ani też dopozwany. Celem działania interwenienta ubocznego jest ochrona własnego interesu prawnego przez pomoc stronie, do której przystępuje, $\mathrm{w}$ tym, aby wygrała sprawę $\mathrm{e}^{3}$. Ochrona ta ma charakter prewencyjny, gdyż umożliwia wsparcie strony procesu w celu zapobieżenia niekorzystnemu rozstrzygnięciu przez pomaganie, kontrolowanie i współdziałanie

* Dr, Katolicki Uniwersytet Lubelski Jana Pawła II; e-mail: paulinawos@kul.lublin.pl.

1 Ustawa z dnia 17 listopada 1964 r. - Kodeks postępowania cywilnego, tekst jednolity: Dz. U. z 2019 r. poz. 1460 z późn. zm. (dalej: k.p.c.).

2 Zob. M. Jędrzejewska, Podmiotowe przekształcenia procesu cywilnego a interwencja uboczna (art. 194-198 k.p.c.), „Nowe Prawo” 1972, nr 2, s. 226.

3 Zob. I. Kunicki [w:] A. Góra-Błaszczykowska (red.), Kodeks postępowania cywilnego, t. 1. Komentarz. Art. 1-729, Warszawa 2016², s. 350. 
ze stroną ${ }^{4}$. Interwenient uboczny, który przystępuje do sprawy nie staje się stroną procesu, lecz osobą trzecią uprawnioną do wstąpienia i działania $\mathrm{w}$ procesie ${ }^{5}$.

Istota przekształcenia podmiotowego, o którym mowa w art. $194 \S 3$ k.p.c., polegającego na prawie powoda do wezwania osoby trzeciej do wzięcia udziału w sprawie w charakterze pozwanego, jest tożsama - jest to umożliwienie podmiotowi wstąpienia do toczącego się już procesu, którego wynik również będzie go dotyczył bezpośrednio. Jednakże osoba trzecia po skutecznym dopozwaniu stanie się, w przeciwieństwie do interwenienta ubocznego, współuczestnikiem, a więc stroną postępowania. Celem przekształceń podmiotowych jest ułatwienie dotychczasowym i przystępującym do procesu podmiotom dochodzenia i obrony swoich praw w ramach jednego i prowadzonego już postępowania ${ }^{6}$.

\section{Interwencja uboczna samoistna}

Interwencja uboczna samoistna nazywana jest także, zamiennie, kwalifikowaną. Cechuje ją to, że $\mathrm{z}$ istoty spornego stosunku prawnego lub z przepisu ustawy wynika, że wyrok w sprawie ma odnieść bezpośredni skutek prawny w stosunku między interwenientem ubocznym a przeciwnikiem strony, do której przystąpił (art. 81 k.p.c.). Tak więc poza więzią prawną, której wyrazem jest interes prawny interwenienta we wstąpieniu do sprawy, łączącą interwenienta ubocznego ze stroną, do której przystępuje, ustawodawca przewidział również istnienie szczególnej więzi interwenienta z przeciwnikiem strony, do której przystępuje. Tego rodzaju powiązanie prawne spowoduje, że wyrok wydany w sprawie odniesie bezpośredni skutek nie tylko między stronami, ale również w stosunku

4 Zob. F.X. Fierich, Strony $i$ ich zastępcy, [w:] Komisja Kodyfikacyjna Rzeczypospolitej Polskiej, Polska Procedura Cywilna: projekty referentów z uzasadnieniem, t. 1, Kraków 1921, s. 62.

5 Zob. M. Jędrzejewska, Podmiotowe przeksztatcenia procesu cywilnego..., s. 226-227; P. Rylski, Udział osób trzecich w procesie cywilnym - perspektywa kodyfikacyjna, [w:] K. Markiewicz, A. Torbus (red.), Postępowanie rozpoznawcze w przyszłym Kodeksie postępowania cywilnego, Warszawa 2014, s. 132; postanowienie Sądu Najwyższego z dnia 11 stycznia 2013 r., I CZ 184/12, LEX nr 1288613.

6 Zob. A. Stempniak [w:] A. Marciniak, K. Piasecki (red.), Kodeks postępowania cywilnego, t. 1. Komentarz. Art. 1-366, Warszawa 20167, s. 954. 
między interwenientem a tym właśnie przeciwnikiem strony, do której chce przystąpić. Rozważana więź prawna pomiędzy interwenientem a przeciwnikiem strony, do której przystępuje, może wynikać ze stosunku prawnego ich łączącego, jak również ze stosunku prawnego łączącego interwenienta ubocznego ze stroną, do której przystąpił. Powiązanie to może również mieć swoje źródło w przepisie ustawy. Istnieje także możliwość kumulacji obu tych podstaw ${ }^{7}$. Tak więc interwencja uboczna samoistna występuje $\mathrm{w}$ tych przypadkach, gdy do udziału w sprawie po stronie powodowej lub pozwanej legitymowanych jest kilka podmiotów, każdy niezależnie od drugiego, a więc w wypadkach legitymacji grupowej, ale nie łącznej, ponieważ wówczas wszystkie legitymowane podmioty musiałyby brać udział w procesie w charakterze współuczestników koniecznych. Jeśli zatem niektórzy z uprawnionych biorą udział w procesie $\mathrm{w}$ charakterze stron, inni mogą przystąpić do niego w charakterze interwenientów - interwencja taka będzie mieć charakter interwencji samoistnej ${ }^{8}$ Najczęściej interwencja uboczna samoistna będzie występowała po stronie powodowej w procesach dotyczących świadczeń niepodzielnych, np. w sprawie z powództwa jednego ze współwłaścicieli o wydanie samochodu, będącego przedmiotem współwłasności (art. 209 k.c. ${ }^{9}$ ). Nie oznacza to jednak, że nie może wystąpić po stronie pozwanej. Tak będzie na przykład w sytuacji, kiedy to nabywca rzeczy lub prawa będącego przedmiotem sporu nie decyduje się na wstąpienie w miejsce zbywcy w myśl art. 192 \& 3 k.p.c., ale chce poprzestać na występowaniu w procesie w charakterze interwenienta ubocznego. Również interwencja uboczna małżonka pozostającego w ustroju wspólności ustawowej po stronie współmałżonka pozwanego o zapłatę długu będzie interwencją kwalifikowaną (art. 41 k.r.o. ${ }^{10} \mathrm{~W}$ zW. $\mathrm{z}$ art. 787 k.p.c.).

7 E. Rudkowska-Ząbczyk, Komentarz do art. 81 KPC, [w:] E. Marszałkowska-Krześ (red.), Kodeks postępowania cywilnego. Komentarz 2019, wyd. 24, Legalis/el. 2019; M. Jędrzejewska [aktualizacja K. Weitz] [w:] T. Ereciński (red.), Kodeks postępowania cywilnego. Komentarz, t. 1. Postępowanie rozpoznawcze, Warszawa 20165 , s. 506-507; taż, Interwencja uboczna samoistna, „Państwo i Prawo” 1971, z. 10, s. 578.

8 Zob. B. Czech [w:] A. Marciniak, K. Piasecki (red.), Kodeks postępowania cywilnego, t. 1, s. 402; P. Rylski, Udział osób trzecich..., s. 133-134.

9 Ustawa z dnia 23 kwietnia 1964 r. - Kodeks cywilny, tekst jednolity: Dz. U. z 2019 r. poz. 1145 z późn. zm. (dalej: k.c.).

10 Ustawa z dnia 25 lutego 1964 r. - Kodeks rodzinny i opiekuńczy, tekst jednolity: Dz. U. z 2019 r. poz. 2086 z późn. zm. (dalej: k.r.o.). 
Bezpośredni skutek, jaki wywiera wyrok między interwenientem ubocznym samoistnym a przeciwnikiem strony, do której przystąpił, polega na objęciu interwenienta ubocznego samoistnego powagą rzeczy osądzonej, mimo że nie jest on stroną postępowania ${ }^{11}$. Ma tu miejsce tzw. rozszerzona prawomocność wyroku ${ }^{12}$. Ponadto, w pewnych przypadkach, wchodzi w grę dalszy skutek wyroku, polegający na jego wykonalności wobec interwenienta, co jest możliwe na podstawie wyraźnego przepisu ustawy, gdy stosunek materialnoprawny między interwenientem a stroną, do której przystąpił, to uzasadnia ${ }^{13}$.

Z uwagi na to, że w przypadku interwencji ubocznej samoistnej wyrok ma odnieść bezpośredni skutek prawny wobec interwenienta, zajmuje on $\mathrm{w}$ procesie pozycję równorzędną do współuczestnika sporu i stosuje się do niego odpowiednio przepisy o współuczestnictwie jednolitym ${ }^{14}$. Nie oznacza to jednakże, że interwenient uboczny kwalifikowany staje się współuczestnikiem jednolitym, a tym samym stroną procesu. Jednakże to odpowiednie stosowanie przepisów o współuczestnictwie jednolitym daje interwenientowi ubocznemu samoistnemu szczególne usytuowanie w procesie ${ }^{15}$. Oznacza przede wszystkim, że czynności procesowe strony są skuteczne wobec niedziałającego interwenienta, ale również, że czynności procesowe interwenienta ubocznego samoistnego są skuteczne wobec niedziałającej strony, a nadto powoduje również, że czynności dyspozytywne strony, tj. zawarcie ugody, uznanie powództwa czy zrzeczenie się roszczenia będą wymagały zgody interwenienta ubocznego ${ }^{16}$. Cofnięcie powództwa także będzie uzależnione od zgody interwenienta ubocznego samoistnego, ponieważ dokonanie czynności przez jednego

11 Zob. B. Czech [w:] A. Marciniak, K. Piasecki (red.), Kodeks postępowania cywilnego, t. 1, s. 402; zob. także postanowienie Sądu Najwyższego z dnia 21 maja 2009 r., I PK 10/09, LEX nr 687069.

12 Zob. art. 365 i art. $435 \S 1$ k.p.c. Szerzej o prawomocności materialnej, zob. R. Czarnecki, Rozszerzona prawomocność materialna wyroku na tle art. 205 pkt 3 K.p.c. i art. 541 § 1 K.p.c., „Nowe Prawo” 1964, nr 10, s. 991-994.

13 Zob. B. Czech [w:] A. Marciniak, K. Piasecki (red.), Kodeks postępowania cywilnego, t. 1, s. 402 .

14 Art. 81 k.p.c. in fine; zob. także wyrok Sądu Apelacyjnego w Krakowie z dnia 21 stycznia 2014 r., I ACa 1400/13, LEX nr 1679934.

15 Zob. A. Zieliński [w:] A. Zieliński (red.), Kodeks postępowania cywilnego. Komentarz, Warszawa $2017^{9}$, s. 182.

16 Zob. wyrok Sądu Najwyższego z dnia 30 października 2008 r., II CSK 251/08, LEX nr 1157550 . 
ze współuczestników jednolitych wywołuje sytuację taką, jakby wszyscy współuczestnicy dokonali tej czynności wspólnie, tak więc jej cofnięcie również musi nastąpić za zgodą wszystkich ${ }^{17}$.

\section{Ograniczenia procesowe interwenienta ubocznego samoistnego}

Interwenient uboczny samoistny może korzystać tylko z takich uprawnień procesowych, które pozostają w dyspozycji strony w chwili dokonywania tych czynności przez interwenienta. Sytuacja procesowa interwenienta ubocznego jest więc uwarunkowana uprawnieniami procesowymi, jakie ma strona na tym etapie postępowania, na którym interwenient do niej przystąpi ${ }^{18}$. Wskazane ograniczenia działania interwenienta ubocznego samoistnego wynikające ze stanu sprawy mają charakter bezwzględny oraz ustawowy. Interwenient uboczny nie może także wnosić o przywrócenie terminu do dokonania czynności procesowej, której termin upłynął przed jego wstąpieniem do sprawy, chyba że wnosi o przywrócenie terminu dla strony, powołując się na okoliczności jej dotyczące ${ }^{19}$.

Przy tym rodzaju interwencji ubocznej ograniczeniem możności dokonywania czynności procesowych przez interwenienta ubocznego jest stadium procesu, w którym interwenient przystąpił do sprawy oraz brak statusu strony, co wyklucza dokonywanie samodzielnie jakichkolwiek czynności o charakterze dyspozytywnym ${ }^{20}$. Oznacza to, że czynności interwenienta samoistnego mogą być sprzeczne z czynnościami strony, do której przystąpił, a strona nie może sprzeciwić się czynności interwenienta ani jej cofnąć. Odpowiednie stosowanie przepisów o współuczestnictwie jednolitym sprawia, że stanowisko procesowe interwenienta ubocznego kwalifikowanego jest w istocie niezależne od woli strony, do której przystąpił, a więc jego czynności mogą być niezgodne z czynnościami

17 Zob. J. Jodłowski [w:] J. Jodłowski, K. Piasecki (red.), Kodeks postępowania cywilnego z komentarzem, t. 1, Warszawa 1989, s. 188.

18 Zob. wyrok Sądu Apelacyjnego w Gdańsku z dnia 9 lutego 2010 r., I ACa 1156/09, LEX nr 604083.

19 Zob. J. Jodłowski [w:] J. Jodłowski, K. Piasecki (red.), Kodeks postępowania cywilnego..., t. 1, s. 186.

20 Zob. K. Flaga-Gieruszyńska, Postępowanie cywilne. Komentarz praktyczny dla sędziów i petnomocników procesowych, Warszawa $2016^{2}$, s. 84. 
strony ${ }^{21}$. W wypadku sprzeczności czynności strony z czynnościami interwenienta ubocznego samoistnego o skuteczności czynności rozstrzyga sąd tak samo, jak w wypadku sprzecznych czynności współuczestników jednolitych ${ }^{22}$.

\section{Wstąpienie interwenienta ubocznego samoistnego do procesu}

Przesłanką dopuszczalności wstąpienia do procesu w charakterze interwenienta ubocznego jest istnienie po stronie osoby chcącej wejść do toczącego się już postępowania interesu prawnego w tym, aby strona, do której przystępuje, wygrała proces. W orzecznictwie Sądu Najwyższego przyjmuje się potrzebę szerokiego rozumienia interesu prawnego, uzasadniającego interwencję uboczną ${ }^{23}$. Gdy wspomniany interes ma charakter bezpośredni i zapadłe orzeczenie wprost wpłynie na ukształtowanie praw i obowiązków interwenienta, zgłaszana interwencja będzie mieć charakter samoistny. Nie ma znaczenia czy jest to prawo albo obowiązek o charakterze majątkowym czy niemajątkowym² ${ }^{24}$ Zawsze jednak związek, o którym mowa, ma mieć charakter normatywny, nie zaś jedynie faktyczny, gospodarczy bądź emocjonalny ${ }^{25}$. Interwencję uboczną może zgłosić osoba trzecia, a więc podmiot prawa niebędący stroną toczącego się postępowania, do którego chce przystąpić.

${ }^{21}$ Zob. Z. Resich [w:] Z. Resich, W. Siedlecki (red.), Kodeks postepowania cywilnego. Komentarz, t. 1, Warszawa 1969, s. 201-202; A. Zieliński [w:] A Zieliński (red.), Kodeks postępowania cywilnego..., s. 182; I. Gromska-Szuster [w:] H. Dolecki, T. Wiśniewski (red.), Kodeks postępowania cywilnego. Komentarz, t. 1. Artykuty 1-366, Warszawa 20132, s. 325; P. Telenga [w:] A. Jakubecki (red.), Kodeks postępowania cywilnego, t. 1. Komentarz do art. 1-729, Warszawa 2017, s. 141; zob. także wyrok Sądu Najwyższego z dnia 30 października 2008 r., II CSK 251/08, LEX nr 1157550; postanowienie Sądu Najwyższego z dnia 21 maja 2009 r., I PK 10/09, LEX nr 687069. Odmiennie, zob. I. Kunicki [w:] A. Góra-Błaszczykowska (red.), Kodeks postępowania cywilnego, t. 1, s. 360.

${ }^{22}$ Zob. I. Kunicki [w:] A. Góra-Błaszczykowska (red.), Kodeks postępowania cywilnego, t. 1, s. 358-359.

${ }^{23}$ Zob. postanowienie Sądu Najwyższego z dnia 3 kwietnia 1973 r., I CZ 27/73, LEX nr 7241.

${ }^{24}$ Zob. I. Kunicki [w:] A. Góra-Błaszczykowska (red.), Kodeks postępowania cywilnego, t. 1, s. 351.

25 Zob. postanowienie Sądu Apelacyjnego w Krakowie z dnia 4 września 2012 r., I ACz 1232/12, LEX nr 1216300. 
Wstąpienie interwenienta ubocznego do sprawy jest czynnością procesową. Forma pisemna interwencji ubocznej jest obligatoryjna także wówczas, gdy osoba zgłaszająca wstąpienie do sprawy w charakterze interwenienta ubocznego stawia się osobiście na terminie rozprawy ${ }^{26}$. Pismo o wstąpieniu do sprawy powinno odpowiadać wymaganiom przewidzianym dla wszystkich pism procesowych ${ }^{27}$, a także dodatkowo powinno zawierać wskazanie interesu prawnego we wstąpieniu interwenienta do sprawy oraz informację, do której strony interwenient uboczny przystępuje. Wskazanie interesu prawnego w piśmie, w którym zgłasza się interwencję uboczną, jest konieczne $\mathrm{w}$ celu zorientowania się przez strony, czy w stosunku do interwencji ubocznej należy zgłosić opozycję ${ }^{28}$. Podanie interesu prawnego nie wymaga jeszcze na tym etapie udowodnienia ani nawet uprawdopodobnienia ${ }^{29}$. Pismo zawierające zgłoszenie interwencji ubocznej powinno zostać wniesione wraz z odpowiednią liczbą odpisów, tak by możliwe było doręczenie zgłaszanej interwencji stronom postępowania. Zgodnie z art. 130 k.p.c. w przypadku braków wskazanych wyżej elementów pisma zgłaszającego interwencję, przewodniczący wzywa zgłaszającego do usunięcia braków pod rygorem zwrotu pisma. Zgłoszenie interwencji ubocznej podlega opłacie sądowej w wysokości $1 / 5$ opłaty należnej od pozwu ${ }^{30}$. Jeżeli kilka osób zgłasza interwencje uboczne w jednym piśmie procesowym, każda z nich uiszcza wpis od swojej interwencji ${ }^{31}$.

Wstąpienie interwenienta ubocznego do sprawy możliwe jest w każdym jej stanie, aż do zamknięcia rozprawy w drugiej instancji (art. 76 k.p.c.).

26 Zob. B. Czech [w:] A. Marciniak, K. Piasecki (red.), Kodeks postępowania cywilnego, t. 1, s. 388; M. Jędrzejewska [aktualizacja K. Weitz] [w:] T. Ereciński (red.), Kodeks postępowania cywilnego..., t. 1, s. 499. Pisemna forma zgłoszenia interwencji ubocznej nie jest konieczna jedynie w tych przypadkach, w których ustawa dopuszcza zgłaszanie ustnie do protokołu powództwa, treści środków odwoławczych i innych wniosków i oświadczeń, czyli w wypadkach określonych w art. 466 k.p.c., odnoszącym się do spraw z zakresu prawa pracy i ubezpieczeń społecznych.

27 Zob. art. 125 i nast. k.p.c.

28 Zob. M. Manowska [w:] M. Manowska (red.), Kodeks postępowania cywilnego. Komentarz, t. 1. Art. 1-505 38 , Warszawa $2015^{3}$, s. 239.

29 Zob. M. Uliasz, Kodeks postępowania cywilnego. Komentarz, Warszawa 2008², s. 116.

30 Art. 19 ust. 3 pkt 1 ustawy z dnia 28 lipca 2005 r. o kosztach sądowych w sprawach cywilnych, tekst jednolity: Dz. U. z 2019 r. poz. 785 z późn. zm.

31 Zob. uchwała Sądu Najwyższego z dnia 10 kwietnia 2003 r., III CZP 20/03, LEX nr 77188. 
Powyższą zasadę słusznie uzasadnia Sąd Najwyższy, twierdząc, że interwencja uboczna jest w ogóle możliwa i dopuszczalna dopóty, dopóki toczy się jeszcze postępowanie w sprawie, a po uprawomocnieniu się orzeczenia sprawa jest już zakończona i odpada potrzeba wspomagania strony $\mathrm{W}$ prowadzeniu procesu przez interwenienta ubocznego ${ }^{32}$. W doktrynie występują dwa różniące się poglądy co do momentu, od którego można skutecznie wystąpić z interwencją uboczną. Część przedstawicieli doktryny uważa, że momentem początkowym zgłoszenia interwencji ubocznej jest chwila, gdy strona, do której przystępuje interwenient uboczny, działa już w toczącym się postępowaniu. Jeżeli zatem interwenient uboczny przystępuje do sprawy po stronie powoda, momentem początkowym będzie wniesienie pozwu, a po stronie pozwanego interwencję można zgłosić dopiero po doręczeniu odpisu pozwu ${ }^{33}$. Natomiast w sytuacji, gdy pozwany zaczyna działać w procesie wcześniej, np. w wyniku wydania przez sąd postanowienia o udzieleniu zabezpieczenia, interwenient uboczny może już wówczas przystąpić do sprawy i zaskarżyć udzielenie zabezpieczenia $^{34}$. Inna grupa przedstawicieli doktryny prezentuje stanowisko, że interwencję można zgłosić - zarówno po stronie powoda, jak i pozwanego - dopiero po doręczeniu odpisu pozwu pozwanemu, ponieważ dopiero z tą chwilą powstaje zawisłość sporu ${ }^{35}$. Ostatnie z zaprezentowanych stanowisk wydaje się być bardziej przekonujące. Przemawia za tym obowiązująca w procesie cywilnym zasada równości stron, która w kontekście zgłoszenia interwencji ubocznej powinna przejawiać się w przyznaniu osobie trzeciej uprawnienia wejścia do procesu zarówno

32 Zob. postanowienie Sądu Najwyższego z dnia 4 lipca 2014 r., I CZ 62/13, LEX nr 1365608.

33 Zob. M. Jędrzejewska [aktualizacja K. Weitz] [w:] T. Ereciński (red.), Kodeks postępowania cywilnego..., t. 1, s. 497-498.

34 Zob. J. Klimkowicz, Interwencja uboczna wedtug kodeksu postępowania cywilnego, Warszawa 1972, s. 32; J. Jodłowski [w:] J. Jodłowski, K. Piasecki (red.), Kodeks postepowania cywilnego..., t. 1, s. 181-182; M. Mizera, Zdolność sąowa, interwencja uboczna oraz postępowanie nakazowe i upominawcze w sprawach gospodarczych, "Nowe Prawo" 1990, nr 10/12, s. 147; M. Sokalski, Przesłanki formalne interwencji ubocznej, "Zeszyty Naukowe Wyższej Szkoły Zarządzania i Prawa" 2005, z. 3, s. 131; zob. także postanowienie Sądu Apelacyjnego w Łodzi z dnia 31 marca 1992 r., I ACz 89/92, LEX nr 9133.

35 Zob. S. Gołąb, Interwencja uboczna, „Palestra” 1934, nr 8, s. 462; W. Siedlecki [w:] W. Siedlecki, Z. Świeboda, Postępowanie cywilne. Zarys wykładu, Warszawa 2004, s. 126; J. Mucha, Zawistość sprawy w procesie cywilnym, Warszawa 2014, s. 226-228; P. Telenga [w:] A. Jakubecki (red.), Kodeks postepowania cywilnego, t. 1, s. 137. 
po stronie powodowej, jak i pozwanej w tym samym momencie, którym powinna być chwila zawiśnięcia sporu.

Czas, w jakim interwencja uboczna może być wniesiona do sądu, nie jest terminem procesowym $\mathrm{w}$ rozumieniu art. 167 i nast. k.p.c. Oznacza to, że jego przekroczenie nie może być konwalidowane przy zastosowaniu instytucji przywrócenia terminu. Spóźnionej interwencji ubocznej nie zostanie nadany bieg, a interwenientowi ubocznemu sąd odmówi dopuszczenia do udziału $\mathrm{w}$ sprawie $\mathrm{w}$ takim charakterze. $\mathrm{Z}$ uwagi na przyczynę niedopuszczenia do udziału w sprawie takie postanowienie nie będzie zaskarżalne na podstawie art. 394 § 1 pkt 3 k.p.c. ${ }^{36}$ Po zamknięciu rozprawy w II instancji niedopuszczalne jest już wniesienie interwencji ubocznej, chyba że sąd apelacyjny uchyli zaskarżone orzeczenie i przekaże sprawę do ponownego rozpoznania sądowi I instancji. Wówczas otwiera się ponownie możliwość zgłoszenia interwencji ubocznej ${ }^{37}$.

Osoba trzecia staje się interwenientem ubocznym z chwilą skutecznego wniesienia do sądu pisma zawierającego interwencję uboczną. Z momentem wstąpienia do sprawy interwenient uboczny staje się - innym niż strona - podmiotem postępowania i przysługują mu w związku z tym wyżej opisane uprawnienia procesowe. Do interwenienta ubocznego będą miały zastosowanie przepisy art. 131-147 k.p.c. o doręczaniu pism oraz zawiadomienia o czynnościach i posiedzeniach sądu ${ }^{38}$. Przedmiotem doręczeń są pisma sądowe, pisma procesowe i orzeczenia sądu.

\section{Skutek interwencyjny}

Istotną konsekwencją zgłoszenia interwencji jest to, że niezależnie od tego, czy interwenient uboczny miał rzeczywiście interes prawny w przystąpieniu do procesu oraz czy strony wniosły opozycję przeciwko jego wstąpieniu, czynność procesowa polegająca na zgłoszeniu interwencji ubocznej wywoła skutek w postaci uruchomienia konsekwencji z art. 82 k.p.c.,

36 Zob. E. Rudkowska-Ząbczyk [w:] E. Marszałkowska-Krześ (red.), Postępowanie cywilne, Warszawa 2017, s. 228.

37 Zob. A. Zieliński [w:] A. Zieliński (red.), Kodeks postępowania cywilnego..., s. 177.

38 Zob. I. Gromska-Szuster [w:] H. Dolecki, T. Wiśniewski (red.), Kodeks postępowania cywilnego..., t. 1, s. 322. 
które to nie mogą zostać zniweczone przez wystąpienie interwenienta ubocznego z procesu ${ }^{39}$.

Zarzut male gesti processus, o którym mowa w art. 82 k.p.c. oznacza, że jeżeli strona przegra proces i wystąpi przeciwko interwenientowi ubocznemu $\mathrm{z}$ roszczeniem regresowym, interwenient uboczny, który działał $\mathrm{u}$ jej boku, nie będzie mógł w stosunku do tej strony podnosić zarzutu, że sprawa została rozstrzygnięta błędnie albo że strona prowadziła proces wadliwie ${ }^{40}$. Wyjątek stanowi sytuacja, gdy interwenient uboczny bez swojej winy przystąpił do procesu w tak późnym jego stadium, że nie miał już możliwości podjęcia właściwego działania, a także, gdy interwenient uboczny miał wprawdzie możliwość podjęcia określonych działań, ale nie wiedział o pewnych środkach dowodowych lub obrony, natomiast strona, wiedząc o nich, w sposób umyślny lub przez niedbalstwo nie skorzystała $\mathrm{z}$ nich ${ }^{41}$. Regulacja art. 82 k.p.c. nie pozwala na rozpatrywanie w postępowaniu regresowym zarzutów odnoszących się do przebiegu i wyniku poprzedniego procesu prowadzonego $\mathrm{z}$ udziałem interwenienta ubocznego $^{42}$. Zatem udział interwenienta ubocznego daje stronie, do której przystąpił, pewność, że nie spotka się ona w przyszłości z zarzutem złego prowadzenia procesu.

Skutek interwencyjny będzie miał miejsce również $\mathrm{w}$ stosunku do przypozwanego $\mathrm{w}$ trybie art. 84 k.p.c. Zgodnie $\mathrm{z}$ art. $84 \S 1$ k.p.c. strona, której w razie niekorzystnego dla niej rozstrzygnięcia przysługiwałoby roszczenie względem osoby trzeciej albo przeciwko której osoba trzecia mogłaby wystąpić z roszczeniem, może zawiadomić taką osobę o toczącym się procesie i wezwać ją do wzięcia w nim udziału. Oczywiście nie w każdym procesie zajdzie konieczność zastosowania instytucji przypozwania. Ocena przypozwania osoby trzeciej zależy od stosunku materialnoprawnego, jaki łączy stronę procesu z osobą trzecią, która może stać się interwenientem ubocznym. Jeżeli owy stosunek może być podstawą ewentualnego procesu między stronami, to instytucja przypozwania znaj-

39 Zob. M. Manowska [w:] M. Manowska (red.), Kodeks postępowania cywilnego..., t. 1, s. 241.

40 Zob. A. Zieliński [w:] A. Zieliński (red.), Kodeks postępowania cywilnego..., s. 182.

41 Zob. M. Manowska [w:] M. Manowska (red.), Kodeks postępowania cywilnego..., t. 1, s. 245; B. Czech [w:] A. Marciniak, K. Piasecki (red.), Kodeks postępowania cywilnego, t. 1, s. $404-405$.

${ }^{42}$ Zob. I. Kunicki [w:] A. Góra-Błaszczykowska (red.), Kodeks postępowania cywilnego, t. 1, s. 368 . 
dzie również zastosowanie w stosunku do osoby, która wstępując do procesu stałaby się interwenientem ubocznym samoistnym.

W przypadku skutecznego przypozwania skutek interwencyjny, o którym mowa w art. 82 k.p.c., powstanie niezależnie od tego, czy przypozwany wstąpił do toczącego się postępowania jako interwenient uboczny, czy też nie zgłosił interwencji ubocznej, a także wówczas, gdy przypozwany zgłosił interwencję uboczną, ale z opóźnieniem. Jeżeli zatem strona dokonała przypozwania w odpowiednim czasie, a przypozwany nie zgłosił interwencji lub zwlekał z jej zgłoszeniem, to na podstawie art. $85 \mathrm{w} z w$. $\mathrm{z}$ art. 82 k.p.c., on - a nie strona - ponosi tego skutki w postaci utraty prawa do zgłoszenia exceptio male gesti processus ${ }^{43} \mathrm{w}$ ewentualnym procesie regresowym.

\section{Przekształcenia podmiotowe $\mathrm{w}$ trybie art. 194 § 3 k.p.c.}

Zmiany podmiotów występujących w charakterze stron Kodeks postępowania cywilnego reguluje w art. 194-196, 198 i 477 k.p.c. Przepisy o przekształceniach podmiotowych znajdują zastosowanie jedynie $\mathrm{w}$ procesie i wyłącznie przed sądem pierwszej instancji ${ }^{44}$. Do podmiotowej zmiany powództwa może dojść w różnych etapach procesu cywilnego. Początkowa chwila możliwego przekształcenia wyznaczona jest czynnością doręczenia pozwu pozwanemu, a końcowa - zamknięciem rozprawy przez sąd I instancji ${ }^{45}$.

Podmiotowe przekształcenia procesu mogą występować w każdego rodzaju sprawie, w której taka potrzeba powstanie w trakcie postępowania ${ }^{46}$.

43 Zob. wyrok Sądu Najwyższego z dnia 14 czerwca 2013 r., V CSK 381/12, LEX nr 1385902; I. Gromska-Szuster [w:] H. Dolecki, T. Wiśniewski (red.), Kodeks postępowania cywilnego..., t. 1, s. 333; I. Kunicki [w:] A. Góra-Błaszczykowska (red.), Kodeks postępowania cywilnego, t. 1, s. 368; B. Czech [w:] A. Marciniak, K. Piasecki (red.), Kodeks postępowania cywilnego, t. 1, s. 411.

44 Zob. A. Zieliński [w:] A. Zieliński (red.), Kodeks postępowania cywilnego..., s. 414; T. Żyznowski [w:] H. Dolecki, T. Wiśniewski (red.), Kodeks postępowania cywilnego..., t. 1, s. 731.

45 Zob. A. Stempniak [w:] A. Marciniak, K. Piasecki (red.), Kodeks postępowania cywilnego, t. 1, s. 954.

46 Zob. M. Jędrzejewska [aktualizacja K. Weitz] [w:] T. Ereciński (red.), Kodeks postępowania cywilnego. Komentarz, t. 2. Postepowanie rozpoznawcze, Warszawa 2016, s. 130. Ju- 
Zmiana podmiotowa powództwa, o której mowa w art. 194 § 3 k.p.c., polega na powiększeniu składu podmiotowego strony pozwanej o podmioty równie legitymowane do występowania $w$ toczącym się procesie, jak te w nim już występujące ${ }^{47}$. Artykuł $194 \S 3$ k.p.c. dotyczy więc wezwania do wzięcia udziału $\mathrm{w}$ sprawie $\mathrm{w}$ charakterze pozwanego osoby, przeciwko której nie zostało wytoczone powództwo. Wezwanie do udziału w sprawie, o którym mowa w art. 194 § 3 k.p.c., zmierza do uzupełnienia legitymacji procesowej biernej, łącznej o charakterze względnym po stronie pozwanej. Legitymacja ta zachodzi wtedy, gdy w roli danej strony procesowej może wystąpić kilka osób ${ }^{48}$. Wezwanie to doktryna i orzecznictwo określają terminem "dopozwania”. Dopozwanie jest możliwe, gdy proces pod względem przedmiotowym nie ulega zmianie ${ }^{49}$, ale sąd nie ma obowiązku prowadzenia dochodzenia w celu ustalenia osoby, przeciwko której powód powinien kierować swoje roszczenie $e^{50}$.

Co istotne, art. $194 \S 3$ k.p.c. nie dotyczy ani następstwa prawnego, ani naprawienia legitymacji procesowej. Pomiędzy osobami już pozwanymi a tymi, które mają być wezwane do udziału w sprawie, musi zachodzić ścisły związek wynikający z łączącego je stosunku prawnego, który sprawia, że tak jak przeciwko pozwanemu, tak samo i w stosunku do nich można wystąpić z tym samym żądaniem. Najczęstszymi przykładami dopozwania w oparciu o art. 194 § 3 k.p.c. są wszystkie przypadki odpowiedzialności solidarnej, in solidum, lub odpowiedzialności opartej na tej samej podstawie faktycznej i prawnej ${ }^{51}$. Pomiędzy pozwanymi, którzy od początku mogli być objęci jednym pozwem występuje współuczestnictwo materialne ${ }^{52}$.

dykatura przyjęła jednak niedopuszczalność stosowania art. $194 \mathrm{w}$ sprawach o ustalenie ojcostwa, zob. uchwała Sądu Najwyższego z dnia 18 czerwca 1968 r., III CZP 69/67, LEX nr 859; uchwała Sądu Najwyższego z dnia 21 kwietnia 1977 r., III CZP 12/77, LEX nr 2145.

${ }_{47}$ Zob. M. Jędrzejewska [aktualizacja K. Weitz] [w:] T. Ereciński (red.), Kodeks postępowania cywilnego..., t. 2, s. 130.

48 Zob. A. Stempniak [w:] A. Marciniak, K. Piasecki (red.), Kodeks postępowania cywilnego, t. 1, s. 961-962.

49 Zob. P. Telenga [w:] A. Jakubecki (red.), Kodeks postępowania cywilnego, t. 1, s. 368; wyrok Sądu Najwyższego z dnia 18 kwietnia 1968 r., III PRN 86/67, LEX nr 767.

50 Zob. wyrok Sądu Najwyższego z dnia 3 lipca 2000 r., II UKN 628/99, LEX nr 49977.

51 Zob. M. Manowska [w:] M. Manowska (red.), Kodeks postepowania cywilnego..., t. 1, s. 569.

52 Zob. E. Rudkowska-Ząbczyk, Komentarz do art. 194 KPC, [w:] E. Marszałkowska-Krześ (red.), Kodeks postępowania cywilnego..., Legalis/el. 2019. 


\section{Wniosek o dopozwanie w trybie art. 194 § 3 k.p.c.}

Przekształcenie podmiotowe, o jakim mowa w art. $194 \S 3$ k.p.c., następuje wyłącznie na wniosek powoda ${ }^{53}$. Sąd nie ma obowiązku podjęcia z urzędu czynności zmierzających do wezwania jeszcze innych osób w charakterze pozwanych ${ }^{54}$. Wyjątkiem jest art. 477 k.p.c., który przewiduje, że $w$ postępowaniu odrębnym $w$ sprawach z zakresu prawa pracy, wszczętym z powództwa pracownika, sąd może dokonać dopozwania także z urzędu. Oznacza to, że wniosek pozwanego o dopozwanie nie może być przez sąd uwzględniony. Taki wniosek, jako niedopuszczalny, podlega odrzuceniu ${ }^{55}$.

Sąd nie bada przyczyn, z powodu których osoba objęta wnioskiem powoda o dopozwanie została przez niego pominięta w pozwie ${ }^{56}$. Możliwość i dopuszczalność uzyskania przez powoda w wytoczonym przez niego procesie rozstrzygnięcia także wobec innych niż pierwotnie wskazani $\mathrm{w}$ pozwie podmiotów uwarunkowana jest jedynie zastrzeżeniem, o którym mowa w zdaniu pierwszym art. 194 § 3 k.p.c.: ,jeżeli okaże się, że powództwo o to samo roszczenie może być wytoczone przeciwko innym jeszcze osobom".

Kodeks postępowania cywilnego nie przewiduje dla wniosku o dopozwanie żadnych wymogów szczególnych. Tym samym, na podstawie art. $125 \S 1$ k.p.c. należy przyjąć, że może być on złożony ustnie na rozprawie, a poza rozprawą - $\mathrm{w}$ formie pisma procesowego, które musi spełniać wymogi pisma procesowego, o którym mowa w art. 126 k.p.c. Wniosek taki powinien zatem wskazywać osobę, której dotyczy wraz ze wskazaniem jej adresu ${ }^{57}$. Do wniosku o dopozwanie powinny zostać dołączone odpisy pism procesowych i załączników dotychczas złożonych w sprawie

53 Zob. wyrok Sądu Najwyższego z dnia 21 lipca 1967 r., II CR 57/67, LEX nr 6199; wyrok Sądu Najwyższego z dnia 11 lipca 1967 r., II CR 119/67, LEX nr 6193.

54 Zob. wyrok Sądu Najwyższego z dnia 17 listopada 2010 r., I CSK 67/10, LEX nr 688666; zob. także K. Piasecki, Podmiotowe przekształcenia procesu po stronie pozwanej, „Nowe Prawo" 1967, nr 9, s. 1110.

55 Zob. H. Pietrzkowski, Przekształcenia podmiotowe w procesie cywilnym, „Przegląd Sądowy" 2002, nr 10, s. 23.

56 Zob. T. Żyznowski [w:] H. Dolecki, T. Wiśniewski (red.), Kodeks postępowania cywilnego..., t. 1, s. 734 .

57 Zob. E. Rudkowska-Ząbczyk, Komentarz do art. 194 KPC, [w:] E. Marszałkowska-Krześ (red.), Kodeks postępowania cywilnego..., Legalis/el. 2019. 
celem doręczenia ich dopozwanemu. $\mathrm{W}$ razie niezłożenia przez powoda odpisów pism i załączników, przewodniczący posiedzenia zarządza sporządzenie tych odpisów przez sekretariat ${ }^{58}$.

Chwila dopozwania jest określona momentem dokonanego wezwania, ale równocześnie zostają zachowane indywidualne terminy określające moment wytoczenia powództwa i doręczenia pozwu dla pozwanego występującego $\mathrm{w}$ procesie od samego początku oraz dla osób wezwanych do toczącego się już postępowania. Sytuacje procesowe i związane z nimi skutki materialnoprawne wynikające $\mathrm{z}$ dochodzenia roszczeń są w tych wypadkach określane indywidualnie dla każdego podmiotu, bez możliwości ich ujednolicenia, ponieważ to przekształcenie procesu nie prowadzi do następstwa procesowego ${ }^{59}$.

Złożenie wniosku o dopozwanie o którym mowa w art. 194 § 3 k.p.c. nie oznacza bezwzględnego związania nim sądu nawet wówczas, gdy okaże się, że wymienione w $\S 3$ art. 194 k.p.c. przesłanki zostały spełnione ${ }^{60}$. Wykładnia językowa art. $194 \S 3$ k.p.c., który brzmi: „sąd może wezwać", a nie "sąd wzywa” wskazuje, że wniosek powoda może zostać oddalony, gdy okoliczności sprawy nie wskazują na celowość żądanego dopozwania ${ }^{61}$. Oddalenie wniosku mogłoby mieć miejsce, gdyby wniosek został złożony na etapie, gdy prawie całe postępowanie dowodowe zostało już przeprowadzone albo gdy, mając na uwadze stan zaawansowania sprawy ${ }^{62}$, sąd uzna to za niecelowe, a stronie nie grozi przedawnienie roszczeń63. Jednakże, zgodnie ze stanowiskiem Sądu Najwyższego ocena,

$58 \S 166$ ust. 2 rozporządzenia Ministra Sprawiedliwości z dnia 18 czerwca 2019 r. Regulamin urzędowania sądów powszechnych, Dz. U. z 2019 r. poz. 1141 z poźn. zm.; zob. także postanowienie Sądu Najwyższego z dnia 7 lutego 1968 r., I PZ 2/68, LEX nr 745 .

59 Zob. M. Jędrzejewska [aktualizacja K. Weitz] [w:] T. Ereciński (red.), Kodeks postępowania cywilnego..., t. 2, s. 135; M. Manowska [w:] M. Manowska (red.), Kodeks postepowania cywilnego..., t. 1, s. 569.

${ }^{60}$ Zob. A. Zieliński [w:] A. Zieliński (red.), Kodeks postępowania cywilnego..., s. 416; zob. także W. Broniewicz, Kilka uwag o znaczeniu wniosków stron i czynnościach sądu przy podmiotowej zmianie powództwa, "Nowe Prawo” 1974, nr 2, s. 194; H. Pietrzkowski, Przeksztatcenia podmiotowe..., s. 24.

61 Zob. wyrok Sądu Najwyższego z dnia 22 grudnia 1975 r., IV PR 274/75, LEX nr 7783.

62 Zob. postanowienie Sądu Najwyższego z dnia 22 lipca 2015 r., I PZ 10/15, LEX nr 1789931.

63 Zob. P. Telenga [w:] A. Jakubecki (red.), Kodeks postępowania cywilnego, t. 1, s. 369. 
że ze względu na zaawansowanie sprawy, nieuzasadnione jest wezwanie do wzięcia w niej udziału dalszej osoby w charakterze pozwanego, może nastąpić jedynie w wypadku wyjątkowym ${ }^{64}$.

Wniosek o dopozwanie podlega rozpoznaniu przez sąd, który wydaje $w$ tym przedmiocie postanowienie. Wobec braku przepisu szczególnego, na podstawie art. $148 \S 1$ k.p.c. należy przyjąć, że może ono zapaść wyłącznie na rozprawie ${ }^{65}$. Orzeczenie to może mieć charakter pozytywny, czego skutkiem będzie wezwanie osoby trzeciej do wzięcia udziału w sprawie w charakterze pozwanego, bądź negatywny, co będzie oznaczało oddalenie wniosku i uniemożliwienie wstąpienia dopozwanego podmiotu do procesu. Na wydane $\mathrm{w}$ tym przedmiocie postanowienia nie służy zażalenie ${ }^{66}$.

Skutki, jakie ustawa wiąże z wytoczeniem powództwa, wobec dopozwanego wywołuje już samo złożenie wniosku przez powoda. Z kolei skutki, jakie ustawa wiąże $\mathrm{z}$ doręczeniem pozwu pozwanemu powstaną wobec dopozwanego zawsze z momentem doręczenia mu postanowienia o dopozwaniu wraz z odpisem pozwu wniesionego $w$ sprawie $^{67}$.

Konsekwencją niewezwania przez powoda do udziału w sprawie niewystępujących, ale posiadających legitymację, podmiotów stanowi uchybienie $\mathrm{w}$ stosowaniu art. 194 \& 3 k.p.c., które jednak nie ma istotnego wpływu na wynik sprawy i nie prowadzi do oddalenia powództwa. Ujemne skutki niezastosowania instytucji dopozwania przewidzianej w art. 194 § 3 k.p.c. wyrażają się jedynie w opóźnieniu w skutecznej i jednorazowej realizacji roszczeń powoda wobec wszystkich podmiotów $\mathrm{w}$ jednym procesie ${ }^{68}$.

64 Zob. postanowienie Sądu Najwyższego z dnia 13 maja 1976 r., II CZ 37/76, LEX nr 5010.

65 Zob. J. Jodłowski, Z problematyki przeksztatceń podmiotowych procesu cywilnego (art. 194 k.p.c. w teorii i praktyce), „Palestra” 1987, nr 9 (357), s. 45.

66 Zob. A. Stempniak [w:] A. Marciniak, K. Piasecki (red.), Kodeks postępowania cywilnego, t. 1, s. 963; postanowienie Sądu Najwyższego z dnia 10 listopada 1970 r., II CZ 139/70, LEX nr 4717.

67 Zob. E. Rudkowska-Ząbczyk, Komentarz do art. 194 KPC, [w:] E. Marszałkowska-Krześ (red.), Kodeks postępowania cywilnego..., Legalis/el. 2019.

68 Zob. T. Żyznowski [w:] H. Dolecki, T. Wiśniewski (red.), Kodeks postępowania cywilnego..., t. 1, s. 736 . 


\section{Zakończenie}

Zarówno interwencja uboczna samoistna po stronie pozwanego, jak i dopozwanie w trybie art. 194 § 3 k.p.c., mają na celu umożliwienie wstąpienia do postępowania osobie trzeciej znajdującej się poza podmiotowymi granicami wytoczonego powództwa, jeżeli tylko pomiędzy stronami procesu a tą osobą trzecią zachodzi ścisły związek wynikający z łączącego je stosunku prawnego, który sprawia, że tak jak przeciwko pierwotnie pozwanemu, tak i w stosunku do tych wstępujących podmiotów można wystąpić z tym samym żądaniem. Pomimo istotnego podobieństwa osiągnięcie rezultatu, jakim jest wejście do procesu osoby trzeciej, podlega odmiennej procedurze. W przypadku interwencji ubocznej wstąpienie do postępowania osoby trzeciej zależy wyłącznie od jej woli. Jeżeli osoba trzecia wykaże interes prawny we wstąpieniu do toczącego się postępowania, to sąd nie może nie dopuścić jej do udziału w sprawie. Dopiero zgłoszenie opozycji i zakwestionowanie interesu prawnego interwenienta przez strony postępowania może pozbawić interwenienta ubocznego prawa do dalszego udziału w postępowaniu, do którego wstąpił. Z kolei w przypadku dopozwania w trybie art. 194 $\S 3$ k.p.c. podmiotem wyłącznie legitymowanym do złożenia wniosku o dopozwanie jest powód - ani pozwany, ani osoba trzecia nie może skutecznie wnosić o dopozwanie. Co więcej, o wstąpieniu do postępowania osoby trzeciej jako współuczestnika decyduje sąd, a nie strona występująca z wnioskiem o dopozwanie. Sąd, w przeciwieństwie do zgłoszenia interwencji ubocznej, w przypadku dopozwania może je oddalić, jeżeli uzna, że jest niecelowe.

Ponadto, w zależności od tego, czy zgłoszona została interwencja uboczna samoistna, czy dopozwanie, różne będą statusy podmiotów, które weszły do toczącego się postępowania. W przypadku zgłoszenia interwencji ubocznej podmiot wstępujący nie stanie się stroną procesu a interwenientem ubocznym, podczas gdy wskutek dopozwania osoba trzecia wezwana do udziału w procesie stanie się współuczestnikiem biernym stroną toczącego się postępowania.

Wydawać by się zatem mogło, że z punktu widzenia stron postępowania korzystniej jest osobę trzecią dopozwać aniżeli wezwać ją do udziału $\mathrm{w}$ postępowaniu w charakterze interwenienta. Niestety ustawodawca nie przyznał ani stronom postępowania, ani też osobom trzecim prawa do dokonywania wyboru pomiędzy zastosowaniem którejś z omawianych 
instytucji. Wezwać inne podmioty do udziału w sprawie w charakterze pozwanych może jedynie strona powodowa, a wniosek pozwanego lub osoby trzeciej w tym zakresie zostanie odrzucony jako niedopuszczalny. Z kolei interwencję uboczną może zgłosić tylko sam zainteresowany przystąpieniem do postępowania. Strony procesu mogą wprawdzie zawiadomić osobę trzecią o toczącym się postępowaniu i wezwać ją do wzięcia $\mathrm{w}$ nim udziału $\mathrm{w}$ charakterze interwenienta ${ }^{69}$, ale ostatecznie to nie one decydują o jej wstąpieniu, gdyż decyzja w zakresie zgłoszenia interwencji ubocznej leży w wyłącznej gestii zawiadomionej osoby trzeciej. Tak więc okazuje się, że obydwie instytucje choć istotnie podobne, różnią się w wielu aspektach procesowych, $\mathrm{w}$ tym przede wszystkim legitymacją do zainicjowania interwencji ubocznej oraz dopozwania. Interwencja uboczna jest drogą wejścia do procesu osoby trzeciej z jej własnej inicjatywy, podczas gdy inicjatywa przekształcenia podmiotowego w trybie art. 194 § 3 k.p.c. należy wyłącznie do powoda ${ }^{70}$.

Słowa kluczowe: interwencja uboczna, dopozwanie, przekształcenia podmiotowe, proces, pozwany

\section{Bibliografia}

\section{Źródła}

\section{Akty prawne}

Ustawa z dnia 25 lutego 1964 r. - Kodeks rodzinny i opiekuńczy, tekst jednolity: Dz. U. z 2019 r. poz. 2086 z późn. zm.

Ustawa z dnia 23 kwietnia 1964 r. - Kodeks cywilny, tekst jednolity: Dz. U. z 2019 r. poz. 1145 z późn. zm.

Ustawa z dnia 17 listopada 1964 r. - Kodeks postępowania cywilnego, tekst jednolity: Dz. U. z 2019 r. poz. 1460 z późn. zm.

Ustawa z dnia 28 lipca 2005 r. o kosztach sądowych w sprawach cywilnych, tekst jednolity: Dz. U. z 2019 r. poz. 785 z późn. zm.

Rozporządzenie Ministra Sprawiedliwości z dnia 18 czerwca 2019 r. - Regulamin urzędowania sądów powszechnych, Dz. U. z 2019 r. poz. 1141 z późn. zm.

69 Przypozwanie, o którym mowa w art. 84 k.p.c.

70 Zob. M. Jędrzejewska, Podmiotowe przekształcenia procesu cywilnego..., s. 234. 


\section{Orzecznictwo}

Uchwała Sądu Najwyższego z dnia 10 kwietnia 2003 r., III CZP 20/03, LEX nr 77188. Wyrok Sądu Najwyższego z dnia 11 lipca 1967 r., II CR 119/67, LEX nr 6193.

Wyrok Sądu Najwyższego z dnia 21 lipca 1967 r., II CR 57/67, LEX nr 6199.

Wyrok Sądu Najwyższego z dnia 18 kwietnia 1968 r., III PRN 86/67, LEX nr 767. Wyrok Sądu Najwyższego z dnia 30 września 1968 r., I CR 224/68, LEX nr 915.

Wyrok Sądu Najwyższego z dnia 22 grudnia 1975 r., IV PR 274/75, LEX nr 7783. Wyrok Sądu Najwyższego z dnia 3 lipca 2000 r., II UKN 628/99, LEX nr 49977.

Wyrok Sądu Najwyższego z dnia 30 października 2008 r., II CSK 251/08, LEX nr 1157550.

Wyrok Sądu Najwyższego z dnia 17 listopada 2010 r., I CSK 67/10, LEX nr 688666. Wyrok Sądu Najwyższego z dnia 14 czerwca 2013 r., V CSK 381/12, LEX nr 1385902.

Postanowienie Sądu Najwyższego z dnia 7 lutego 1968 r., I PZ 2/68, LEX nr 745.

Postanowienie Sądu Najwyższego z dnia 10 listopada 1970 r., II CZ 139/70, LEX nr 4717.

Postanowienie Sądu Najwyższego z dnia 3 kwietnia 1973 r., I CZ 27/73, LEX nr 7241.

Postanowienie Sądu Najwyższego z dnia 21 maja 2009 r., I PK 10/09, LEX nr 687069.

Postanowienie Sądu Najwyższego z dnia 4 lipca 2014 r., I CZ 62/13, LEX nr 1365608.

Postanowienie Sądu Najwyższego z dnia 22 lipca 2015 r., I PZ 10/15, LEX nr 1789931.

Wyrok Sądu Apelacyjnego w Gdańsku z dnia 9 lutego 2010 r., I ACa 1156/09, LEX nr 604083.

Wyrok Sądu Apelacyjnego w Krakowie z dnia 21 stycznia 2014 r., I ACa 1400/13, LEX nr 1679934.

Postanowienie Sądu Apelacyjnego w Łodzi z dnia 31 marca 1992 r., I ACz 89/92, LEX nr 9133.

Postanowienie Sądu Apelacyjnego w Krakowie z dnia 4 września 2012 r., I ACz 1232/12, LEX nr 1216300.

\section{Literatura}

Broniewicz W., Kilka uwag o znaczeniu wniosków stron i czynnościach sądu przy podmiotowej zmianie powództwa, „Nowe Prawo” 1974, nr 2, s. 192-199.

Czarnecki R., Rozszerzona prawomocność materialna wyroku na tle art. 205 pkt 3 K.p.c. i art. 541 § 1 K.p.c., „Nowe Prawo” 1964, nr 10, s. 991-994.

Czech B. [w:] A. Marciniak, K. Piasecki (red.), Kodeks postępowania cywilnego, t. 1. Komentarz. Art. 1-366, Warszawa 20167', s. 378-411. 
Dolecki H., T. Wiśniewski (red.), Kodeks postępowania cywilnego. Komentarz, t. 1. Artykuty 1-366, Warszawa $2013^{2}$.

Ereciński T. (red.), Kodeks postępowania cywilnego. Komentarz, t. 1. Postępowanie rozpoznawcze, Warszawa $2016^{5}$.

Ereciński T. (red.), Kodeks postępowania cywilnego. Komentarz, t. 2. Postępowanie rozpoznawcze, Warszawa $2016^{5}$.

Fierich F.X., Strony i ich zastępcy, [w:] Komisja Kodyfikacyjna Rzeczypospolitej Polskiej, Polska Procedura Cywilna: projekty referentów z uzasadnieniem, t. 1, Kraków 1921, s. 44-78.

Flaga-Gieruszyńska K., Postępowanie cywilne. Komentarz praktyczny dla sędziów i petnomocników procesowych, Warszawa $2016^{2}$.

Gołąb S., Interwencja uboczna, „Palestra” 1934, nr 8, s. 461-472.

Góra-Błaszczykowska A. (red.), Kodeks postępowania cywilnego, t. 1. Komentarz. Art. 1-729, Warszawa $2016^{2}$.

Gromska-Szuster I. [w:] H. Dolecki, T. Wiśniewski (red.), Kodeks postępowania cywilnego. Komentarz, t. 1. Artykuty 1-366, Warszawa 2013², s. 301-333.

Jakubecki A. (red.), Kodeks postepowania cywilnego, t. 1. Komentarz do art. 1-729, Warszawa $2017^{7}$.

Jędrzejewska M., Interwencja uboczna samoistna, „Państwo i Prawo” 1971, z. 10, s. 578-593.

Jędrzejewska M., Podmiotowe przeksztatcenia procesu cywilnego a interwencja uboczna (art. 194-198 k.p.c.), „Nowe Prawo” 1972, nr 2, s. 224-235.

Jędrzejewska M. [aktualizacja K. Weitz] [w:] T. Ereciński (red.), Kodeks postępowania cywilnego. Komentarz, t. 1. Postepowanie rozpoznawcze, Warszawa 20165, s. 495-513.

Jędrzejewska M. [aktualizacja K. Weitz] [w:] T. Ereciński (red.), Kodeks postępowania cywilnego. Komentarz, t. 2. Postepowanie rozpoznawcze, Warszawa $2016^{5}$, s. $129-135$.

Jodłowski J., K. Piasecki (red.), Kodeks postepowania cywilnego z komentarzem, t. 1, Warszawa 1989.

Jodłowski J. [w:] J. Jodłowski, K. Piasecki (red.), Kodeks postępowania cywilnego z komentarzem, t. 1, Warszawa 1989, s. 181-186.

Jodłowski J., Z problematyki przekształceń podmiotowych procesu cywilnego (art. 194 k.p.c. w teorii i praktyce), "Palestra” 1987, nr 9 (357), s. 36-56.

Klimkowicz J., Interwencja uboczna wedtug kodeksu postępowania cywilnego, Warszawa 1972.

Kunicki I. [w:] A. Góra-Błaszczykowska (red.), Kodeks postępowania cywilnego, t. 1. Komentarz. Art. 1-729, Warszawa 2016², s. 349-368.

Manowska M. (red.), Kodeks postępowania cywilnego. Komentarz, t. 1. Art. 1-50538, Warszawa $2015^{3}$. 
Manowska M. [w:] M. Manowska (red.), Kodeks postępowania cywilnego. Komentarz, t. 1. Art. 1-50538, Warszawa $2015^{3}$, s. 238-247.

Marciniak A., K. Piasecki (red.), Kodeks postępowania cywilnego, t. 1. Komentarz. Art. 1-366, Warszawa 2016 .

Markiewicz K. , A. Torbus (red.), Postępowanie rozpoznawcze w przyszłym Kodeksie postepowania cywilnego, Warszawa 2014.

Marszałkowska-Krześ E. (red.), Kodeks postępowania cywilnego. Komentarz, wyd. 17, Legalis/el. 2016.

Marszałkowska-Krześ E. (red.), Kodeks postępowania cywilnego. Komentarz 2019, wyd. 24, Legalis/el. 2019.

Marszałkowska-Krześ E. (red.), Postępowanie cywilne, Warszawa 2017.

Mizera M., Zdolność sądowa, interwencja uboczna oraz postępowanie nakazowe i upominawcze w sprawach gospodarczych, "Nowe Prawo” 1990, nr 10/12, s. 142-152.

Mucha J., Zawisłość sprawy w procesie cywilnym, Warszawa 2014.

Piasecki K., Podmiotowe przekształcenia procesu po stronie pozwanej, "Nowe Prawo” 1967, nr 9, s. 1097-1111.

Pietrzkowski H., Przekształcenia podmiotowe w procesie cywilnym, "Przegląd Sądowy" 2002, nr 10, s. 19-36.

Resich Z. [w:] Z. Resich, W. Siedlecki (red.), Kodeks postepowania cywilnego. Komentarz, t. 1, Warszawa 1969, s. 197-207.

Resich Z., W. Siedlecki (red.), Kodeks postępowania cywilnego. Komentarz, t. 1, Warszawa 1969.

Rudkowska-Ząbczyk E., Komentarz do art. 81 KPC, [w:] E. Marszałkowska-Krześ (red.), Kodeks postepowania cywilnego. Komentarz 2019, wyd. 24, Legalis/el. 2019.

Rudkowska-Ząbczyk E., Komentarz do art. 194 KPC, [w:] E. Marszałkowska-Krześ (red.), Kodeks postepowania cywilnego. Komentarz 2019, wyd. 24, Legalis/el. 2019.

Rudkowska-Ząbczyk E. [w:] E. Marszałkowska-Krześ (red.), Postępowanie cywilne, Warszawa 2017, s. 224-237.

Rylski P., Udział osób trzecich w procesie cywilnym - perspektywa kodyfikacyjna, [w:] K. Markiewicz, A. Torbus (red.), Postępowanie rozpoznawcze w przyszłym Kodeksie postępowania cywilnego, Warszawa 2014, s. 103-154.

Sokalski M., Przestanki formalne interwencji ubocznej, "Zeszyty Naukowe Wyższej Szkoły Zarządzania i Prawa" 2005, z. 3, s. 125-136.

Siedlecki W. [w:] W. Siedlecki, Z. Świeboda, Postępowanie cywilne. Zarys wykładu, Warszawa 20045 , s. 124-128.

Stempniak A. [w:] A. Marciniak, K. Piasecki (red.), Kodeks postepowania cywilnego, t. 1. Komentarz. Art. 1-366, Warszawa 20167', s. 952-965.

Telenga P. [w:] A. Jakubecki (red.), Kodeks postepowania cywilnego, t. 1. Komentarz do art. 1-729, Warszawa 2017, s. 136-144.

Uliasz M., Kodeks postępowania cywilnego. Komentarz, Warszawa $2008^{2}$.

Zieliński A. (red.), Kodeks postępowania cywilnego. Komentarz, Warszawa $2017^{9}$. 
Zieliński A. [w:] A. Zieliński (red.), Kodeks postępowania cywilnego. Komentarz, Warszawa 20179', s. 175-184, 414-416.

Żyznowski T. [w:] H. Dolecki, T. Wiśniewski (red.), Kodeks postępowania cywilnego. Komentarz, t. 1. Artykuty 1-366, Warszawa 20132', s. 730-736.

\section{SECONDARY INDEPENDENT INTERVENTION ON THE PART OF THE DEFENDANT AND SUBJECTIVE TRANSFORMATION IN THE MODE OF ART. 194 § 3 OF THE CODE OF CIVIL PROCEDURE}

\section{Summary}

It may happen that after initiating a civil trial, it turns out that in the initiated proceedings there are not all entities directly interested in its resolution. The Code of Conduct provides for two different, albeit essentially similar, institutions that allow access to proceedings already pending to other entities than originally indicated in the action of a party to the proceedings. Both the institution of the secondary intervention and the subjective transformations are the institutions provided for by the Code of Civil Procedure only for a trial. Depending on the mode of initiating entry into the process, the person joining it becomes a secondary intervenient or a defendant co-participant in the proceedings.

This study deals with the issue of independent (qualified) secondary intervention and one of several types of subjective transformations in the proceedings - additional summons in accordance with art. $194 \S 3$ CCP. The aim of this paper is to discuss and attempt to confront both institutions in order to answer the question about the meaning of reporting secondary intervention in the context of the possibility of adding a third party to the proceedings.

Key words: secondary intervention, additional summons, subjective transformation, proceedings, defendant

\section{САМОПРОИЗВОЛЬНОЕ ВМЕШАТЕЛЬСТВО СО СТОРОНЫ ОТВЕТЧИКА И СУБЪЕКТИВНОЕ ПРЕОБРАЗОВАНИЕ В СООТВЕТСТВИИ СО СТ. 194 § 3 ГРАЖДАНСКОГО ПРОЦЕССУАЛЬНОГО КОДЕКСА}

Резюме

Может случиться так, что после возбуждения гражданского судебного разбирательства выясняется, что в возбужденном разбирательстве присутствуют не все субъекты, непосредственно заинтересованные в его урегули- 
ровании. Процессуальный кодекс предусматривает два различных, хотя и по существу схожих, института, которые позволяют другим сторонам вступать в незавершенное производство, а не сторонам процесса, первоначально указанным в иске. Как институт побочного вмешательства, так и субъективные преобразования являются институтами, предусмотренными Гражданским процессуальным кодексом исключительно для судебного разбирательства. В зависимости от способа инициирования вступления в процесс лицо, присоединяющееся к судебному разбирательству, становится сторонним вмешательством или соучастником ответчика в процессе.

Это исследование затрагивает вопрос о спонтанном (квалифицированном) побочном вмешательстве, происходящем на стороне ответчика, а также об одном из нескольких типов предметных трансформаций в процессе - дополнительном вызове по ст. 194 § 3 Гражданского процессуального кодекса.

Цель этой работы - обсудить и попытаться противостоять обоим учреждениям, чтобы ответить на вопрос о смысле сообщения о побочном вмешательстве в контексте возможности привлечения третьей стороны к участию в судебном процессе.

Ключевые слова: побочное вмешательство, обвинительное заключение, субъективная трансформация, судебное разбирательство, ответчик 